\title{
コンクリート構造物表面のひびわれ測定のための階層構造化画像処理
}

\section{Hierarchical Image Processing for Crack Measurement on Concrete Structures.}

\author{
土居原健*・織田和夫*・広野貴一*・笠井靖浩**・ \\ 木村鷹志**・大沼一彦***.安田 嘉純*** \\ Takeshi DOIHARA, Kazuo ODA, Kichi HIRONO, Yasuhiro KASAI, \\ Takashi KIMURA, Kazuhiko OHNUMA and Yoshizumi YASUDA
}

\begin{abstract}
As assessment of crack width with precision of the order of 10-1 $\mathrm{mm}$ is required in periodical crack inspection of concrete structures, crack measurement has been performed by using crack-scale manually and/or by using image processing with close range photograph. In the image processing especially, closer photograph images are required for more precise measurement of cracks, which usually have width of about $0.1 \mathrm{~mm}$, because of the restriction of inherent resolving power of imaging devices.

This paper presents a crack measuring algorithm in which images of different resolution are generated from a closer range photograph and hierarchically structured from fine to coarser in order to extract concrete crack automatically by using a single spatial filter rather than using a series of spatial filters. And it is also designed to offer processing time saving from data exploding of closer range imaging with high-resolution.

As a result of experiments, more than $80 \%$ of cracks above $0.1 \mathrm{~mm}$ width are extracted automatically and RMS. error in measuring crack width is performed less than $0.19 \mathrm{~mm}$. It is concluded that our approach to crack measurement shows much possibility of a practical crack measuring system, which can be substituted for a conventional measurement in human-dependent inspection.
\end{abstract}

\section{1.はじめに}

荷重作用や塩害・中性化，アルカリ骨材反応・凍結 融解・乾燥収縮などによるコンクリート構造物の劣化 は，現象としてひびわれを伴うことが多い。さらにそ のひびわれが鉄筋腐食あるいは強度・弾性の低下，漏 水・気密性の低下，美観の低下など，他の劣化現象の 誘引となっていることが多く，発生しているひびわれ の量を把握することがコンクリート構造物の健全度を 評価する重要な指標となると考えられている。また， 先の劣化原因で発生するひびわれには構造物の各部位 の主鉄筋方向に対する規則性の有無など，形状パ夕一 ンに特長があり，それによる劣化原因の推定も試みら

* アジア航測(株) Asia Air Survey Co., Ltd.

** 東京電力 (株) Tokyo Electric Power Co.

***千葉大学: Chiba Univ.

「写真測量とリモートセンシング」VOL. 37，NO. 3， 1998
れている1。このため, コンクリート構造物を保守管理 する上でひびわれの状況を定量的に把握することは， 劣化の進行性を判定したり原因を推定するために極め て有用である。

コンクリート構造物表面のひびわれ測定は, 従来か ら定期的な点検において目視や簡易な測定器を用いて 行われてきた。例えば, $0.04 \sim 1.4 \mathrm{~mm}$ まで数種類の線 幅が刻まれたクラックスケールによりひびわれ幅を読 み取り, 形状パターンは現場でのスケッチやチョーク によるマーキングの後, 写真撮影し図に展開して求め ている。また，測定後のひびわれデータの解析はひび われ長，ひびわれ幅あるいは最大ひびわれ幅を例之ば 床版パネル毎などの所定の面積単位に集計して行って いる。しかし，このような測定を行うには多くの人手 と時間が必要なため, ひびわれを写真撮影し画像処理 により迅速に測定する装置が求められている。

類似の装置として路面計測車がある。路面を撮影し ひびわれの形状パターンを画像処理して抽出するが, 
自動化には問題も残されている。それらは，

$\langle 1\rangle$ 表面の污れにより単純な 2 值化が困難

〈2〉 測定要求が詳細になるに従って画像化密度が 高まり，デー夕量が膨大となる

〈3〉 自然光の下では画像取得の制御が困難

である。島村 ${ }^{2)}$ は線構造としてのひびわれに着目し, 前 処理によるテクスチャノイズの低減とデー夕縮小の手 法を提案した。他方，コンクリート構造物のひびわれ 測定では形状パターンを抽出するだけでなく, 幅が 0.1 $\mathrm{mm}$ 程度の微小なひびわれまでその幅を測らなければ ならない。ひびわれは路面のようなマクロ視点では直 感的に画像上の線画素列と捉えられるが, $0.1 \mathrm{~mm} の ミ$ クロな視点では幅 $2 \mathrm{~mm}$ 程度のひびわれでも带領域 を形成する。このため，その抽出には単純な線画素列 に対する画像処理が適用できない（問題〈 4$\rangle ）$ という 新たな問題が生じている。

本研究では, 上記〈 1$\rangle,\langle 2\rangle,\langle 4\rangle$ の問題に対して 注目すべき箇所はより詳細にそれ以外は概観するパー パシブ・ビジョン的な処理概念を応用し, 階層構造化 した画像をもとにひびわれが存在する部分のみ詳細に 処理する一方で, 存在しない部分は処理から除外する という選択的な coarse to fine 画像処理によるひびわ れ測定方法を提案する。本論では以下にひびわれ測定 方法の基本的な考之方を概説した後，その処理手法に ついて述べる。次に実際のコンクリート構造物表面の ひびわれ写真に対して処理手法を適用し，その有効性 を検証する。なお，照明光の問題く $3>$ は人工照明を用 いて撮影をコントロールすることとし，ここでは議論 しない。

\section{2. 基本的な考え方}

\section{1 画像によるひびわれ測定の課題}

コンクリート標準仕方書によれば，コンクリート構 造物のひびわれはかぶり厚にもよるが，概ね幅 $0.3 \mathrm{~mm}$ が点検の基準となる3)。したがって，画像によるひびわ れ測定はそれ以下の例えば幅が $0.1 \mathrm{~mm}$ 程度のひびわ れまで行うことが測定要求となる。このような要求に 従うとすると, 画像は測定值に求められる有効桁数に 見合う十分な解像度で取得しておく必要があるため, 例之ば 4 画素 $/ 0.1 \mathrm{~mm}$ 幅の密度， 8 bit 階調/ 1 画素の モノクロ画像として高々 $1 \mathrm{~m} \times 1 \mathrm{~m}$ のコンクリート 面を画像化したとしてもデータ量は約1.6GBにも達
する。そのため, 一様な画像処理では計算コストがか かりすぎ，効率的な処理が不可久となる。

また，幅 0.1 数 $\mathrm{mm}$ のひびわれを測定対象とした とき, $0.1 \mathrm{~mm}$ のひびわれは画像上で高々数画素幅の線 画素列であるのに対して, 幅数 $\mathrm{mm}$ のひびわれは幅数 十画素の帯領域を形成する。そのため, ひびわれを抽 出する画像処理はUびわれ幅に応じて線画素列を処理 する手法を選択するか, 長く太い帯領域を処理する手 法を選択するかしなければならず，幅に無関係に一意 的に定めることができない。

さらに，コンクリート構造物の表面には污れの付着 や変色，骨材の凹凸による影など，ひびわれ以外の明 暗がある。このため, 線画素列あるいは帯領域のいず れの処理の場合にも，ひびわれを単純に画像の明暗に よって 2 值化するのは難しい。処理対象となるひびわ れがひびわれ幅により画像としての特徵を変えている ため，その 2 值化には線画素列と帯領域の抽出を複合 し，かつ各々の特徵を捉えた 2 值化閾值の計算法が必 要である。

\section{2 想定するひびわれ測定装置}

コンクリート構造物のひびわれ測定には上述の測定 要求がある一方で，巡視点検時の使用を前提とする携 行性も要求されている。CCD 撮像装置も高密度化され ているが，現状ではコストや画像取得の容易さ，画像 密度などの点からフィルムカメラによる撮影と画像処 理の方法を取らざるを得ない。そこで，本研究ではひ びわれ測定装置として困 1 を想定する。

図 1 は携行可能な $70 \mathrm{~mm}$ カメラによる測定対象面の スポット的な撮影，撮影フィルムのデジタル化，画像 処理によるひびわれの形状パターンの抽出と幅の測 定，原因を推定するひびわれデー夕の解析など，装置 の機能構成を示す模式困である。測定対象とするひび われは幅 $0.1 〜 2 \mathrm{~mm}$ である。撮影に複写用マイクロ フィルムを用いると, フィルムの解像性 ${ }^{4) 5} に よ り$ 縮尺 $1 / 10$ が撮影条件となり，70mm フィルムでは $50 \mathrm{~cm} \times$ $50 \mathrm{~cm}$ のコンクリート面が 1 ショットの撮影範囲とな る。画像は 4 画素 $/ 0.1 \mathrm{~mm}$ 幅を実現することとし，フィ ルムを密度 $2.5 \mu$ で読み取りデジタル化する。

\section{3 画像の階層化と coarse to fine 画像処理の適用}

処理対象デー夕の増大とパターン認識の問題には従 来から画像の階層構造化手法が研究6)7(8)9110)されてき 


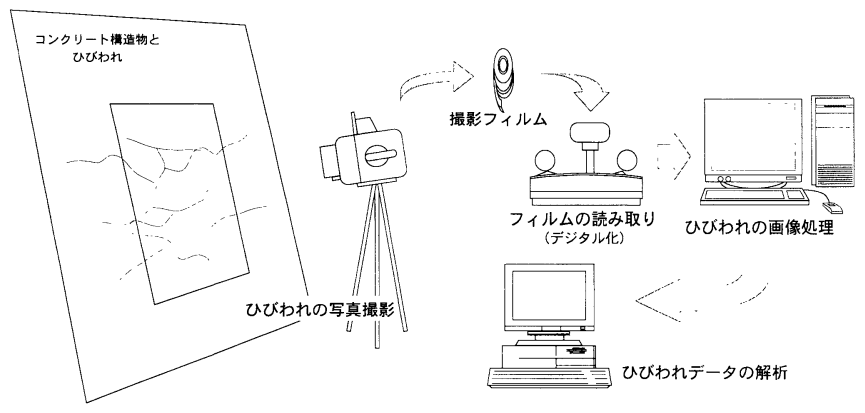

図 1 ひびわれ測定装置の概念図

た。例えばステレオマッチングにおいては coarse to fineによりマッチング精度を向上させている。この処 理概念はひびわれ測定においてもマクロな画像からひ びわれを線画素列として抽出した後，ミクロな視点で 幅を精細処理する手法として応用可能と考えられる。

しかし, coarse to fineによっても精細画像の段階で 全画像を処理したのでは2.1項に示した計算コストの 問題は解決されない。また，階層構造化はミクロとマ クロな視点の融合には有効であるが, これには粗い画 像上でも0.1mm 幅のひびわれ情報が保持されていな ければならない。したがって, 階層構造化の手法を適 用するには異なった幅のひびわれ情報を保持する画像 の縮小法が必要である。さらに, coarse to fine の過程 においても表面のテクスチャ・ノイズを分離しながら ひびわれを 2 值化しなければならず，その手法も必要 となってくる。

そこで，コンクリート構造物表面のひびわれ測定方 法として図 2 に示す階層構造化した画像をべースとす る処理手法を考案した。処理の第 1 はフィルムの読み 取り後, 先ず画像をミクロ視点からマクロ視点まで階 層的に構成することである。この階層構造化では微細 ひびわれの線構造を保存し, かつノイズを低減する論 理フィル夕処理を行い, 測定対象とするひびわれを単 純な線画素列の抽出問題として取り扱えるよう変換す る画像縮小法を考えた。処理の第 2 は coarse to fine によりひびわれを 2 值化し, 形状パターンの抽出とひ びわれ幅の算出を行うことである。表面のテクス チャ・ノイズの影響を除き, かつ計算コストを下げる ため, ここではその過程をさらに 2 分し, 第 1 段階と して最も粗い画像から線画素列の 2 值化を行j（図 2 の概略のひびわれ抽出とひびわれ幅の算出)。第 2 段階 が詳細なひびわれ抽出とひびわれ幅の算出であり, 粗 い画像から順にフィルムの読み取り原画像に至るまで
の処理である。ここでは局所的に 2 值化小領域を決定 し, その領域に逐次, 繰返し判別 2 值化法を適用して 2 值化閾值を自動決定する手法を考えた。また, 画像 が精細になるにつれ増加するデー夕量に対しては，ひ びわれの形状パターンが存在する部分のみ詳細な処理 の対象とするパーパシブ・ビジョン的処理を行うこと により計算コストの低下を図った。なお，ひびわれ幅 の算出には概略の方法として直線オペレー夕法を, 詳

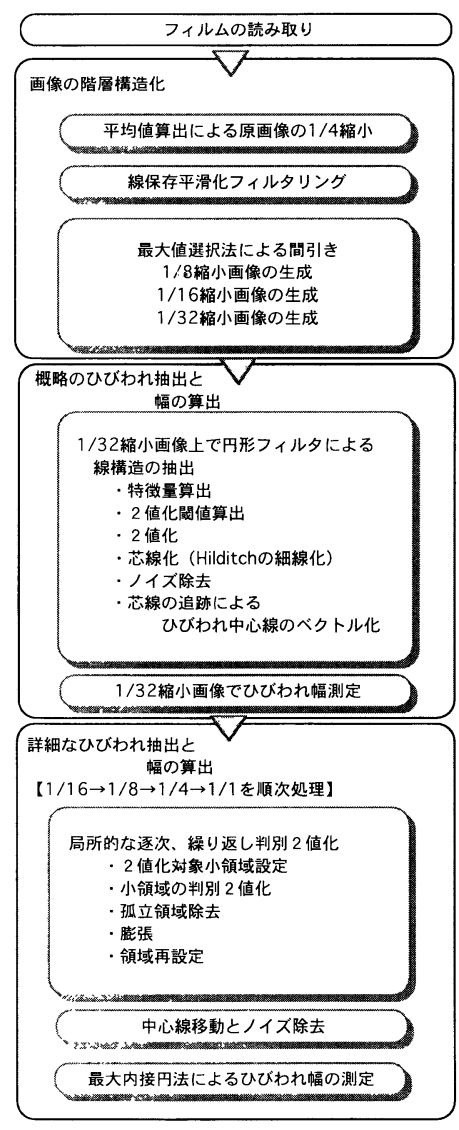

図 2 階層構造化した画像によるひびわれ測定の考え方 
細な方法として最大内接円法を各々考えた。

\section{3.ひびわれ測定のための画像処理手法}

本研究ではひびわれ部を暗部として高デー夕值，コ ンクリート部を明部として低データ值となるように画 像デー夕を作成しており，これを前提として手法を説 明する。

\section{1 階層構造化（線構造保存の縮小）}

図 3 に示すように読み取った原画像から始めに $1 /$ 4 縮小画像を生成し, 順次, 幅 $2 \mathrm{~mm}$ のひびわれを数 画素幅の線構造とみなすのに十分な縮率までの縮小画 像を生成し階層構造化する。後述の円形フィルタの作 用性をみると 3 画素幅までの線構造に強く反応するた め, 目的のひびわれ幅を検出するには $1 / 32$ 縮小画像ま で生成すれば良いことが分かる。また，縮小後も細い ひびわれ情報を保持させなければならないため，縮小 方法は $1 / 4$ 縮小画像の場合には平均化と単純間引き， それ以下の縮小には線構造を残す線保存平滑化フィル タリングと最大值選択による方法を考えた。

\section{（i ）原画像の $1 / 4$ 縮小}

最初の縮小は最小検出ひびわれ幅 $0.1 \mathrm{~mm}$ が画像の 1 画素となるような原画像の縮小である。ミクロな視 点では表面の微細な凹凸により画像に明暗ノイズが生 じている。そこで， 4 画素× 4 画素の16画素から平均 值算出し，この值を新たな 1 画素とすることによりラ ンダムノイズを $1 / 4$ に低減させる ${ }^{11 \mathrm{a})}$ 。0 $0.1 \mathrm{~mm}$ 幅のU びわれが $0.1 \mathrm{~mm}$ 間隔で繰り返し発生する形状パター

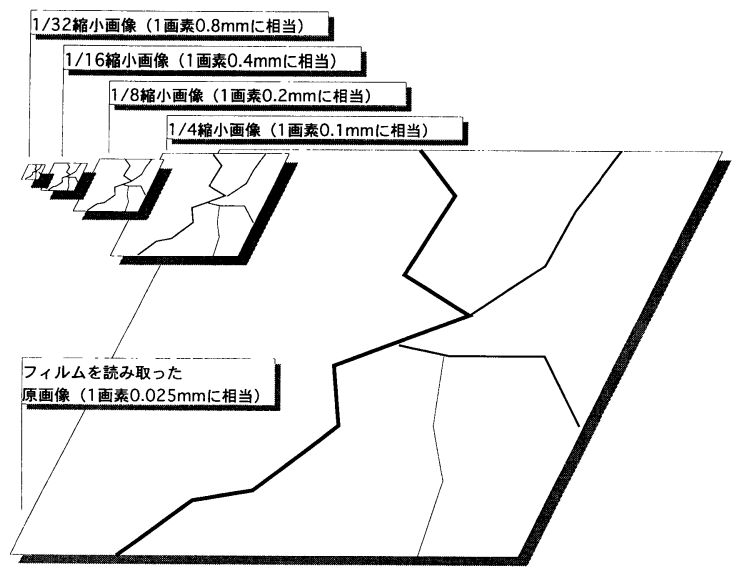

図 3 ひびわれ画像の階層構造化
ンは現実には存在し難いと考えられるため, 平均化を 行っても疑似解像度の発生 ${ }^{11 \mathrm{~b})}$ はなく, 画像のエッジは 鈍るがひびわれの形状パターンは保存されると考えた。

（ii） 線保存平滑化フィルタリングと最大值選択によ る間引き

$1 / 4$ 縮小以降では細いひびわれ線構造を保持する ことを目的として以下の縮小法を採用する。図 4 (1) に示すように，先ず $1 / 4$ 縮小画像の各点 $(i, j)$ を中 心に第 1 第 8 方向にそれぞれn 画素長の平均值 AVEm, $m=1 \sim 8$ を計算し, AVEm の中から最大值 を検索して点 $(i, j)$ の值とする。線状に平均值を求め ることによりひびわれなど線構造を構成している点列 の一部の点 $(i, j)$ では值に変化はないが，それ以外の 孤立した暗部では値が平滑化される。次にひびわれ部 分がコンクリート部分よりも画像デー夕值が大きいこ とから, 図 4 (2)に示すよjに $2 \times 2$ の 4 画素の中か ら最大值を選び画像を間引きする。この処理によって 細いひびわれは細い線のままに残され，他方，幅の太 いひびわれは徐々に細い線構造に変換される。

後述する円形フィル夕の処理は，ひびわれ部とコン クリート部の画像デー夕值の比が大きいほど線構造の 指標となる特徵量が大きく算出され線抽出に有利とな る。これに反し, 縮小に最大值選択による間引きを行 うため，必然的にコンクリート部のデー夕值は高くな り比が低下する。平滑化は円形フィル夕を効果的に作 用させるため，孤立暗部のデー夕值を下げておくため に必要な処理である。なお，フィル夕の長さは最も縮 小した時の 1 画素に相当するように， $n=8$ とする。

\section{2 概略のひびわれ抽出と幅の算出}

エッジがやや鈍ったルーフ型エッジの抽出は文 献8)12)13)のレビュ一や, 図 5 に示す円形フィル夕14)が提 案されている。この中で後者は経験的ではあるがエッ ジの強さから 2 值化閾値が自動決定でき, 背景の明暗 変化に比較的強いという利点がある。そこで，1/32縮 小画像における概略のひびわれ抽出に際し円形フィル 夕の応用を考えた。

\section{（i） 円形フィルタによる特徵量算出}

図 5 に示す円形フィルタを画像に作用させると画素 $O$ について（1）式により特徵量 $S$ が算出される。 $S=W_{T} /\left\{\Sigma\left(W_{B i}-\operatorname{Max} W_{B i}\right) / 7\right\}$ ここで， $W_{T}, W_{B i}$ は画素 $O$ および $O$ を中心とし半径 $R, i$ 番目 $(i=1 \cdots 8)$ の方向にある各々のウィンド 


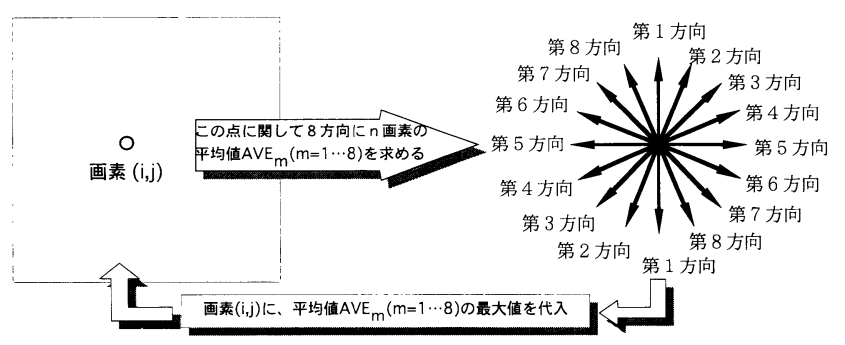

（1） 線保存平滑化フィルタリング

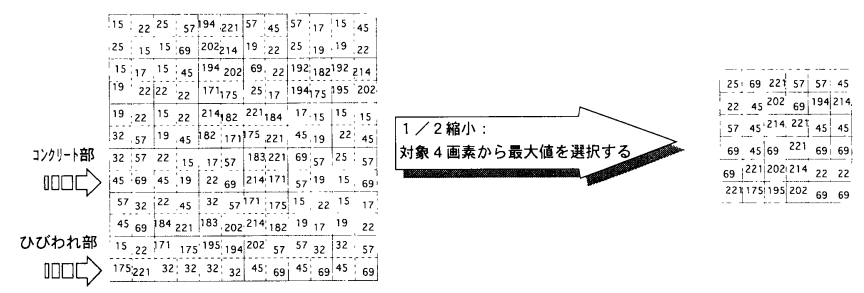

（2）最大值選択による間引き

図 4 線保存平滑化フィルタリングと最大値選択による間引き

ウの画像デー夕平均值, $\operatorname{Max} W_{B i}$ は $W_{B i}(i=1 \cdots 8)$ の中の最大值, $W S$ は処理ウィンドウの大きさ, $g_{n}$ は ウィンドウ中心の極座標である。

図 6 は $R=5, W S=1$ として, 幅が $1 \sim 8$ 画素の ルーフ型エッジの特徴量 $S$ をひびわれ部に対するコ ンクリート部の画像データ值の比（本論では, この比 を仮にコントラストと呼ぶ）を変化させながらシミュ レーションした結果である。ノイズの混入を無視する と, 線幅が 3 画素以下のエッジに良く反応し， 4 画素 以上で鈍くなるのが分かる。すなわち，1/32縮小画像 なら幅が $2 \mathrm{~mm}$ 以下のひびわれに対して作用が期待 できる。

しかし，コンクリート面に污れが多く，黒くなる(コ ントラストが 1 に近づく) と特徵量 $S$ は低下する。こ のことは明暗の差が大きな幅広のルーフ型エッジが付 近にあると特徴量 $S$ が逆転することを示している。し たがって特徴量 $S$ からひびわれを 2 值化するには, 2 值化領域内でひびわれ部とコンクリート部のコントラ ストを同一に保つか，コントラスト別に領域を区分し 2 值化閾值を算出しなければならない。

\section{(ii） 2 值化闇値の算出}

画像のコントラストに影響をあたえるような領域と してのデー夕変化を検出するには画像の領域分割法が

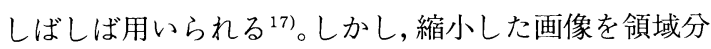
割するとひびわれ部分もセグメント内に取り込まれ， コンクリート部分の暗部とひびわれの暗部を再度区分
する閾値決定が新たな問題となる。本研究では, コン トラストによる領域区分によらず画像全体を小ブロッ クに分け，この中ではコントラストを一様とみなし特 徵量の逆転を抑えることを考えた。具体的には小ブ ロック毎に特徴量 $S$ の平均值 $S_{A V E}$ を算出し 2 值化閾 值の決定を図った。なお， 2 值化閾值は $S_{A V E}$ の1.1倍 を適用 ${ }^{14)}$ した。

\section{（iii） 2 值化・芯線化・ノイズ除去とベクトル化}

小ブロック毎に算出した閾值によりひびわれを 2 值

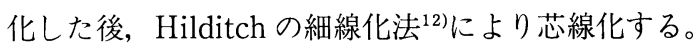
細線化アルゴリズムの特徵として生じるヒゲ状ノイズ は縮退により，閉ループは穴ウメの後，再芯線化によ り除去する。その他, 孤立点や短線も除去する。ノイ ズ処理の後, 芯線を追跡しベクトル化して概略のひび

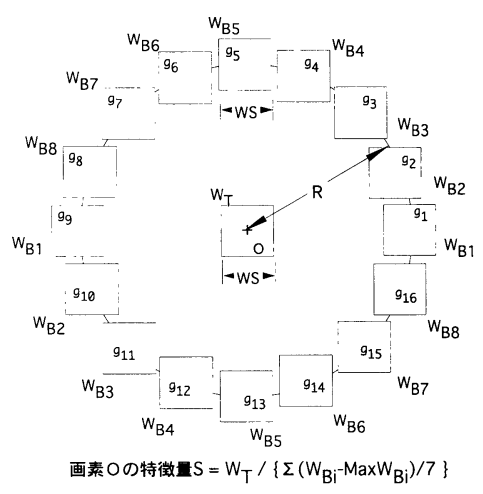

図 5 円形フィルタの模式図と特徵量 S（鈴木, 1985） 


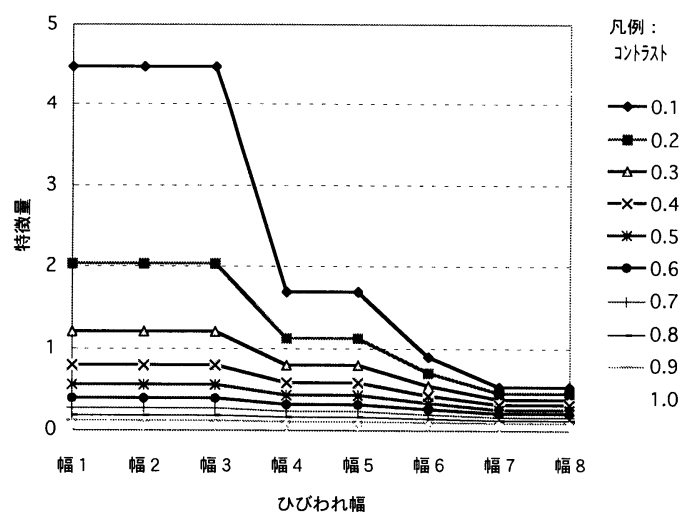

図 6 画像のコントラストの変化に伴う特徵量の変動

われ中心線とする。

\section{（iv） 概略のひびわれ幅の算出}

概略のUびわれ幅は coarse to fine のための初期値 となる。ひびわれ幅は coarse to fineにより徐々に測 定精度が高まるため，ここでは原理が単純で計算コス トの低い直線オペレータ $A$ （図 7 参照）により概略の ひびわれ幅 $w$ を算出する。

直線オペレータ $A=\left\{a_{i}\right\},(-k \leqq i \leqq k)$

ここで,

$S=\left\{a_{j}\right\},(j=-m,-m+1, \cdots, 0, \cdots, n-1, n)$

$T=\left\{a_{J}\right\},(J=-k, \cdots,-m-1$, および, $n+1, \cdots, k)$

$-k \leqq-m \leqq 0,0 \leqq n \leqq k,(S, T \subseteq A)$ とするとき， $D(m, n)=|s-t|$, (ただし, $s$ と $t$ は $S, T$ の平均値)

を最大とする $m, n$ の組から，

$w=m+n+1$

を決定する。

\section{3 詳細なひびわれの抽出と幅の算出}

$1 / 32$ 縮小画像で抽出したひびわれ中心線とひびわ れ幅を初期値として縮小した順と逆順に段階的に精細 な画像内のひびわれを探索し, 中心線の再決定とひび われ幅の再算出を行う。これをフィルム読み取り原画 像まで行いひびわれ測定の精度を向上させる。

\section{（i ）局所的な逐次, 繰返し判別 2 值化}

粗い画像から求めた中心線位置 $\left(x_{u p}, y_{u p}\right)$ と幅 $w_{u p}$ を 1 段階精細な縮小画像に移すには,

$(x, y)=\left(2 x_{u p}\left[\right.\right.$ or, $\left.2 x_{u p}+1\right], 2 y_{u p}\left[\right.$ or, $\left.\left.2 y_{u p}+1\right]\right)$ $w \leqq 2 w_{u p}$
とすればよい。ここで， $x, y, w$ は 1 段階精細な縮小 画像上の位置と幅, 添字 upは粗い画像を表す。した がって，精細な画像でひびわれを 2 值化するにはひび われ中心線が位置する部分のみ選択的に処理すればよ く，この位置参照により計算コストを抑えることがで きる。

また, 画像の 2 值化には判別 2 值化法 ${ }^{15)}$ が一般的で ある。しかし，この手法には 2 值化対象と背景の面積 割合が極端に偏っていると適正な 2 值化閾值が算出さ れないという問題がある16)。このためUびわれが少な いとき，あるいは表面全体が污れているなどノイズが 多いときには画像強調などの前処理が必要となる2)。 これに対して本研究ではひびわれ中心線と幅が概略で はあるが既知である。このことから，図 8 に示すよう に幅 $w$ に応じて扁平率の異なる楕円形の 2 值化小領 域を設けることにより面積割合の極端な偏りが回避で きると考えた。しかし，概略のひびわれ幅 $w_{u p}$ は縮小 画像で簡易に算出したため曖昧であり, また幅の細い ひびわれは縮小の際, 平滑化後も残る周囲のノイズが 取り込まれて構造化されている可能性がある。そこで, coarse to fine ではこれらの影響を抑えるために [ 2 值 化 $\rightarrow$ 孤立領域除去 $\rightarrow$ 澎張 $\rightarrow 2$ 值化領域再決定］をルー プする繰返し 2 值化を考えた。すなわち 2 回目以降の 2 值化に際しては孤立領域の除去後，2值化結果を膨 張させその範囲を楕円に代わって 2 值化小領域に設定 し直す。これにより 2 回目以降の 2 值化にはノイズの 持つデータ分散が 2 值化閾値の算出に取り込まれ難く なる。また, 膨張回数も面積割合の変化を抑之るため ひびわれ幅に応じて可変とし, 判別 2 值化の問題と， イズ混入への対応を図った。ループの終了は前回の 2 值化結果と今回の結果を比較し変化がなくなった時と

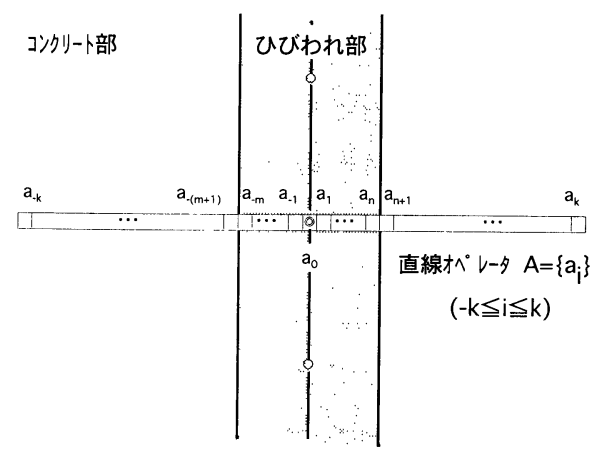

図 7 直線オペレータによるひびわれ幅算出の模式図 


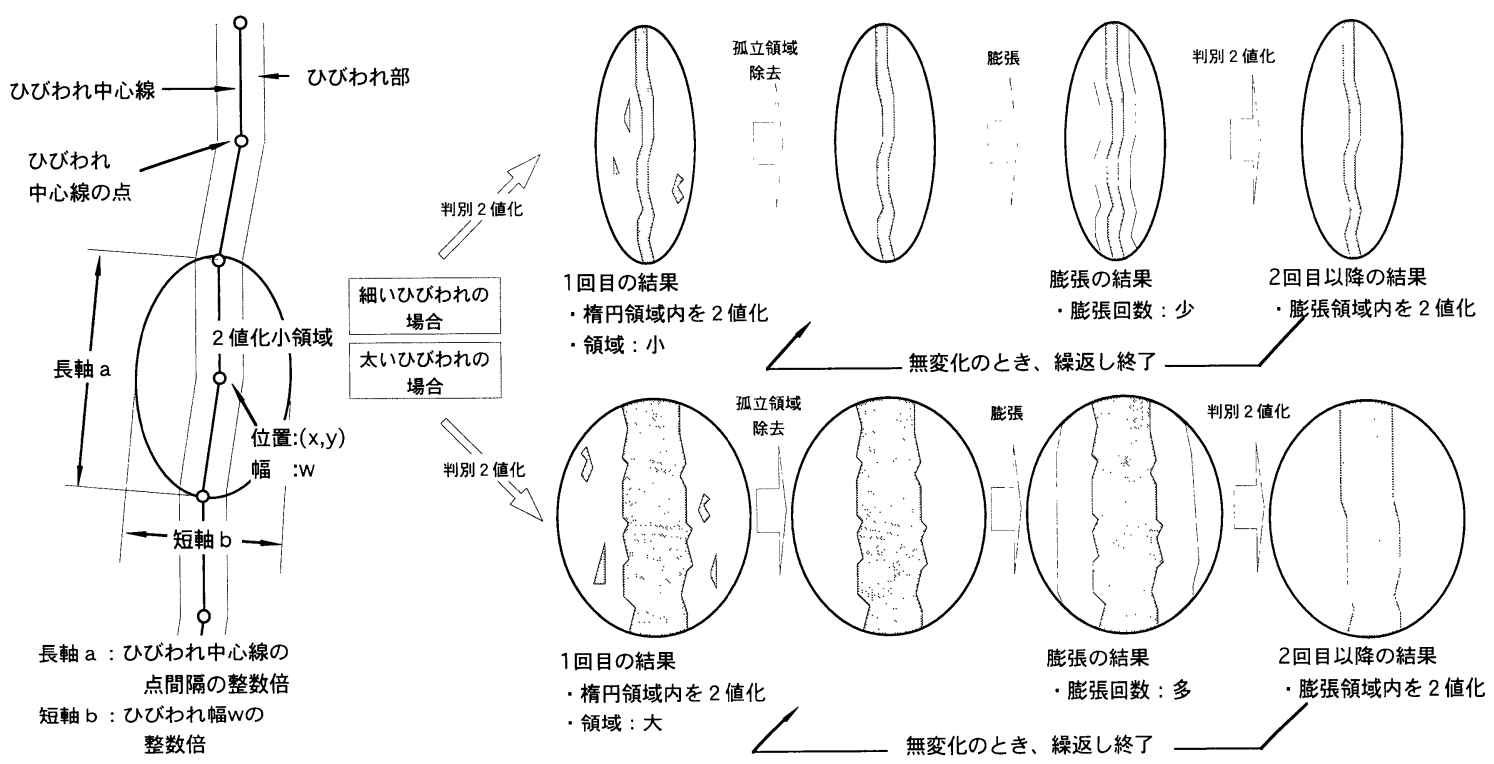

図 8 繰返し判別 2 值化の模式図

し，ひびわれ中心線の全点に設けた楕円小領域を個別 に2 值化し，結果を繫ぎ合わて処理が終了する。

\section{（ii） 中心線移動とノイズ除去}

図 9 に示すように中心線の方向と直交する方向に エッジを探索し, 両エッジの中央を新たに中心線の位 置と決める。このとき概略のひびわれ抽出で部分的に ノイズに中心線が置かれていたとすると, 精細な処理 の後, ひびわれの連続性に矛盾が生じる。そこで, 眓 10に示すようにひびわれにラベリングし中心線の各点 のラベルを求める。ここで各点のラベルがその前後点 のラベルの多数と一致しないとき, 中心線の方向と直 交する方向にUびわれを探索する。このような多数決 によって中心線をより確からしい近傍領域に移動させ 矛盾の解消を図った。

\section{（iii）詳細なひびわれ幅の算出}

詳細なひびわれ幅の算出は, 単純膨張と縮退による ひびわれの穴埋めの後, 困10に示すように中心線の方 向と直交する方向に円の中心を摇らしながら最大内接 円を検索する。ひびわれ中心線の各点について最大内 接円を求めて直径をひびわれ幅とする。

\section{4. 実験}

\section{1 実験フローとパラメータ}

実験は四 2 のフローに従い表 1 に示すパラメー夕を 与えて行った。なお，詳細なひびわれの抽出の際，局
所的な逐次, 繰返し判別 2 值化を幅 $1 \mathrm{~mm}$ 以上のひび われに適用すると幅が細く算出される傾向にあること が予備実験により分かった。そこで，2 值化時の過度 な瘦せ細りを抑えるため概略のひびわれ幅 $w_{u p}$ と画 像間倍率 $S C$ の積が,

$8 \leqq w_{u p} \times s c$

$s c=[$ 処理対象画像の縮小率 $] /(1 / 32)$

となるとき, 繰り返し回数を 1 , 膨張回数を 0 に制限 し実験を進めることとした。

\section{2 検証方法}

提案するひびわれの測定方法は最も縮小した画像で $0.1 \mathrm{~mm}$ 幅のひびわれ情報が保存されていることを前 提とし，ここで抽出された形状パターンを元に詳細な 処理を進めている。したがって，処理の妥当性は概略 のひびわれ抽出の段階で漏れなく，かつノイズの影響

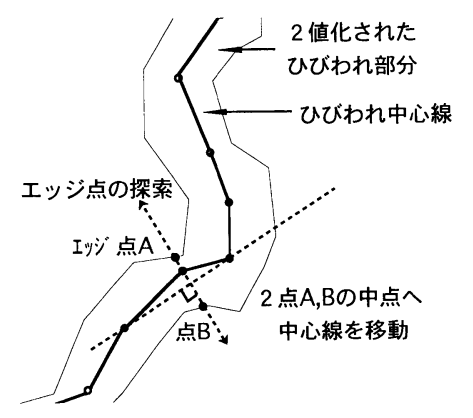

図 9 

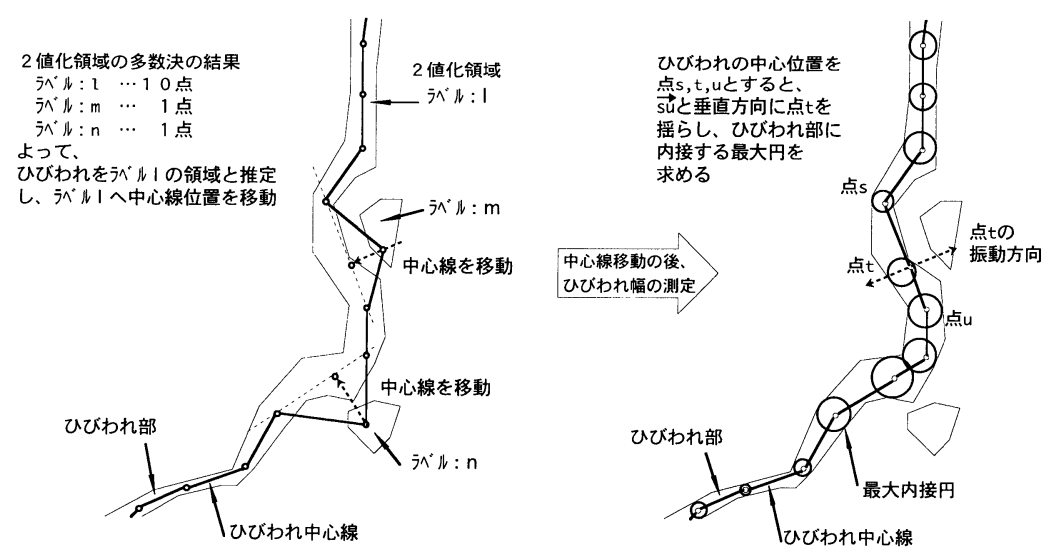

図10 多数決によるノイズの除去（左）と最大内接円法によるひびわれ值の算出（右）

が少なく形状パターンが抽出できたかによって判断で きる。また， 2 值化の妥当性はひびわれ幅の算出精度 により確かめることができる。そこで，画像処理によ る結果を画像上でマニュアル測定した結果に比較し,

(11)～(13) 式の指標を算出して手法を検証することと した。ここで, L Lall は抽出対象とする幅 $0.1 \mathrm{~mm}$ 以上の ひびわれ全長， $L_{\text {corr }}$ は正しく自動抽出したひびわれ 長, $L_{\text {incorr }}$ は誤って抽出した線長, $W_{\text {auto }}$ は最大内接円 法による幅， $W_{\text {man }}$ はマニュアル測定した幅，NS は画 像毎の検査点数である。

1 ）ひびわれの抽出率として認識率と誤認率

$$
\begin{aligned}
& \text { 認識率 }=L_{\text {corr }} / L_{\text {all }} \\
& \text { 誤認率 }=L_{\text {incorr }} / L_{\text {corr }}
\end{aligned}
$$

2 ) ひびわれ幅の測定精度として標準誤差

標準䛊差 $=\left[\Sigma\left(W_{\text {auto }} \cdot i-W_{\operatorname{man}} \cdot i\right)^{2} /(N S-1)\right]^{1 / 2}$,

$$
(i=1, \cdots, N S)
$$

\section{3 実験サンプル}

実験に用いた画像サンプルを図11にまとめて示す。 サンプルはコンクリート面を $70 \mathrm{~mm}$ フィルムを用いて 縮尺が概ね $1 / 10$ となるように(カメラの設置位置の制 限から厳密に $1 / 10$ 縮尺ではない)撮影し，フィルムを 密度 $2.5 \mu$ /画素でデジタル化したものである。

なお，検証には対象となる構造物のひびわれ状態や 表面の污れ状態を定量化し，これを基準として抽出率 や精度を評価するのが望ましいが, 実際の構造物のU びわれ状態は多種・多様, 污れも環境により種類や程 度が様々なため, その定量化は困難であった。そこで, この実験では表現の曖昧さを許すとして，サンプルを ひびわれの分布状況とコンクリート表面の污れにより
次のように区分した。

No. 1 : 打設直後のコンクリート・ブロックにひび われを発生させたサンプルで, 污れが無い

No. 2：比較的污れが少なく細いひびわれの多いサ ンプル

No. 3：一部に石灰の析出と水の滲み出しが見られ るサンプル

No. 4：污れが比較的多く黒いサンプル

\section{5. 結果と評価}

\section{1 画像処理の結果}

\section{（i ）ひびわれの抽出率}

画像処理した結果を表 2 と図12にまとめて示す。表 2 に示すとおり污れの少ないサンプルNo. 1 と No. 2 ではひびわれの抽出は $100 \%$ 可能であった。これより細 いひびわれ情報が縮小後も保持され, 円形フィル夕に より抽出可能なことが分かる。また, やや污れた場合 (No. 3 とNo. 4 ) にも $80 \%$ 近くのひびわれを正しく抽 出できることが確かめられた。反対に抽出ができな かった部分は, No. 3 では画像中央部の部分的に石灰 が析出した箇所や，ひびわれ内に砂が詰まり画像では 途切れたように見える箇所, 污れた水の垂れ落ちが带 状にみられる箇所である。No.4 では番号札左側の污 れた箇所が抽出漏れとなった。

一方, 誤認率は数\% (No. 3) から約 $40 \%$ (No. 2) となっている。ひびわれと誤認したものはNo.1 と No. 2 ではコンクリート打設時に使用した板枠の木目 痕である。これらは実際に細い筋状の明暗をつくって おり,これをひびわれと誤った。また, No. 4 では点在 
表 1 検証実験で設定した各種パラメータと值

\begin{tabular}{|c|c|}
\hline 項 目 & テストに用いた設定值など \\
\hline \multicolumn{2}{|c|}{ 撮影とフィ仙ムの読み取り } \\
\hline ひびわれ撮影 & 搆造物 $50 \times 50 \mathrm{~cm}$ を縮尺 $1 / 10$ で撮影 \\
\hline 扴ジナ娦ジ外画像の密度 & 実構造物上で $0.025 \mathrm{~mm} /$ 画素 \\
\hline \multicolumn{2}{|c|}{ 画像の階層構造化 } \\
\hline 画像デ -タの縮小 & 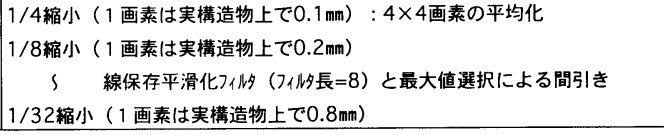 \\
\hline \multicolumn{2}{|c|}{ 概略のひびわれ抽出と幅の算出 } \\
\hline $\begin{array}{l}\text { 線構造の抽出 } \\
\text { 芯線化 }\end{array}$ & $\begin{array}{l}\text { 円形フ似法: } W S=1, R=5, \text { 特徵量平均による } 2 \text { 值化閥値係数 }=\times 1.1 \\
\text { Hilditchの細線化法 }\end{array}$ \\
\hline 1亿除去 & 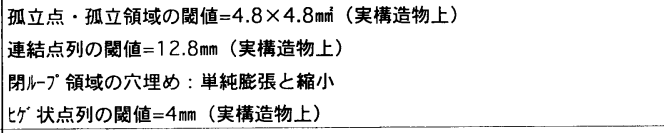 \\
\hline 概略ひびわれ幅の算出 & 直線オへ・レ-タ法 \\
\hline \multicolumn{2}{|c|}{ 詳細なひびわれの抽出と幅の算出 } \\
\hline 局所的な逐次、繰返し 2 值化 & 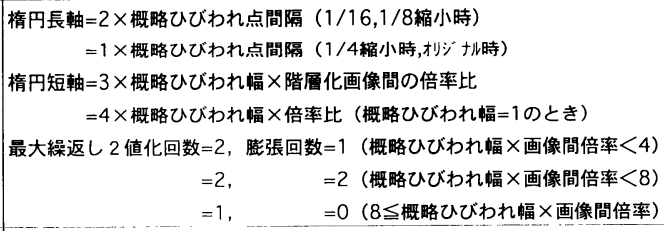 \\
\hline 1亿元除去 & $\begin{array}{l}\text { 穴埋め: 単純胿張と縮小 } \\
\text { 多数決による孤立点・領域除去 }\end{array}$ \\
\hline ひびわれ幅の算出 & $\begin{array}{l}\text { 最大内接円探索による内接円直径 } \\
\text { ひびわれ幅測定間隔 }=0.8 \mathrm{~mm} \text { （1/32縮小時の画像密度に相当） }\end{array}$ \\
\hline
\end{tabular}

する黒いシミの輪郭エッジをひびわれと䛊っている。

なお，図12はひびわれ測定の対象範囲（図11の4 隅 のマークや測定枠を置いた範囲）の他に，参考のため 画像全体を自動処理した結果を表示している。ただし， 表 2 の抽出率や測定精度の算出には測定範囲外のノイ ズはカウントしていない。また, 範囲内にあっても実 験用のマークや番号札, 測定枠など, 本来, コンクリー 卜面に存在しない実験材のエッジ長も計算から除外し ている。

\section{（ii）ひびわれ幅の測定精度}

提案する手法ではひびわれ中心線の全点に対して幅 を算出する。点の間隔は撮影縮尺により若干変化する が, 概ね0.8〜 $1 \mathrm{~mm}$ 間隔であり, 各サンプルはひびわ れ長に比例して $1000 〜 3300$ 点の測定点を持っている。 表 2 は画像サンプル毎にその測定点から無作為に20点 を抽出して求めた標準䛊差である。結果は $0.12 \sim 0.19$ $\mathrm{mm}$ となった。また, 図13には散布図を示す。ノイズ の影響が現れ当初の目標よりやや誤差が大きく測定さ れたが，図13の散布図を併せてみると0.1〜2.0mmの 範囲で概ねひびわれ幅が測定可能なことが分かる。

誤差が大きい点は, 僅かに途切れたせん断ひびわれ
がノイズにより見かけ上，連結したひびわれとなり測 定された簓所 (No.1)，ひびわれの分岐部分で内接円 が大きくなった箇所 (No.2), Uびわれの角が落ち画 像でエッジが不鮮明に写された箇所 (No.3), ひびわ れに剥離や骨材痕が重なった箇所（No.4）であった。

\section{2 評 価}

測定結果とともに一部で発生した細部におけるひび われの抽出エラーについて, 図14を参照しながら手法 の有効性を検討する。

\section{（i）線構造を保存した画像データの階層構造化}

四12のひびわれ抽出結果 (No.1やNo.2) に示した とおり, 細いひびわれやひびわれに似た細い筋も抽出 されており，線構造を保存した階層構造化は機能して いる。ただし，この例のように明暗のみによって抽出 した線構造は最終的にヒトがひびわれか否かを判定し なければならず，抽出したひびわれ候補と原画像を重 ねて表示し，容易にチェックや修正が行える機能が害 用システムの開発に際して不可欠であることが分かっ た。 


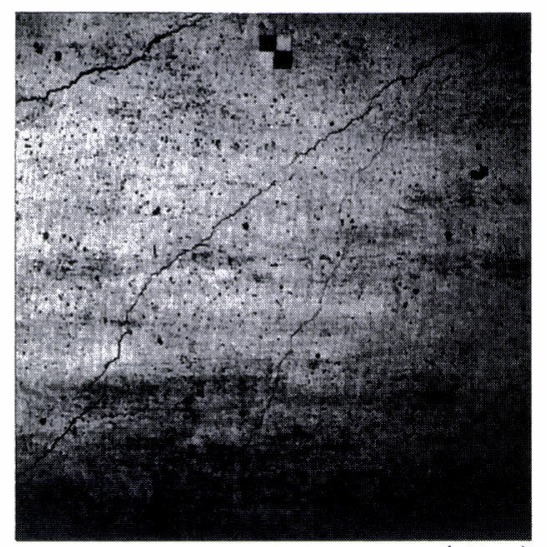

サンプル №. 1

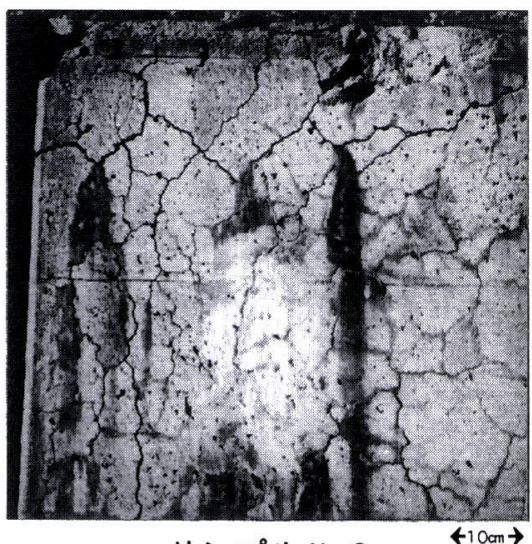

サンプル №. 3

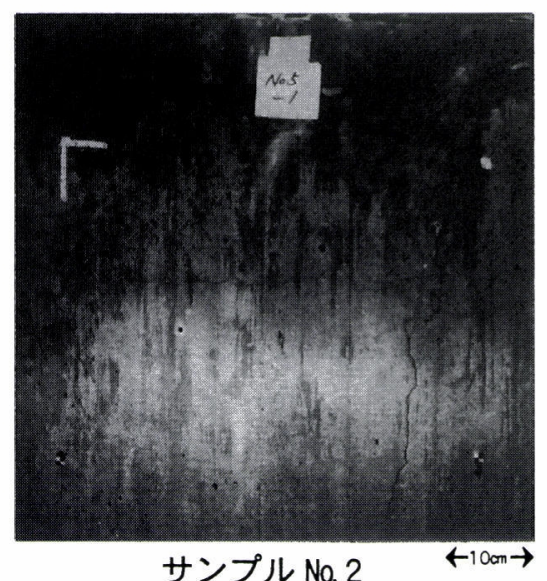

サンプル №.2

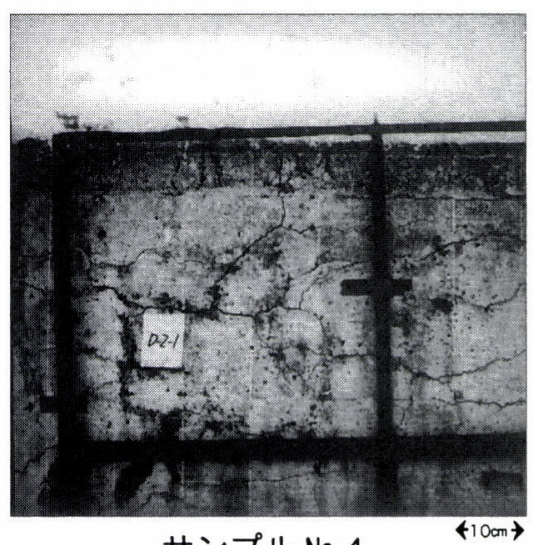

サンプル №. 4

図11 コンクリートひびわれサンプル 4 例

\section{（ii） 円形フィルタによるひびわれの抽出}

円形フィルタの作用性はルーフ型エッジの幅とコン トラストにより変化することを予測し，組み合わせに よっては抽出される線構造が逆転する可能性を示した (図 6 )。この現象がサンプル No. 1 やNo. 2,No. 4 に 現れている。図11, 眓12を見るとコンクリート面に書 いた白線や番号札，測定枠のエッジに円形フィルタが 反応しているのが分かる。従来のひびわれ検査ではコ ンクリート面にチョークでマーキングすることが多 く, 実験結果はこのようなマーキングがひびわれ抽出 の妨げとなることを示唆している。表面の黒いコンク リート面に白いマークがあると，コントラストの高い マークの特徵量が大きく算出され，2 值化閾值が押し 上げられる。その結果，周囲のひびわれは閾值を下回 り抽出漏れとなる。白線など極端な明部は計算から除 外するなど，これらに対する新たな処理が必要なこと
が分かった。

また，サンプルNo. 4 の左上部は全体に暗くコント ラストが低いにもかかわらずひびわれが正しく抽出さ れている。逆に右下部は明るい反面, 点在する污れ領 域の輪郭をひびわれとして誤認している。左上部の結 果は画像を小ブロックに分け 2 值化閾値を設定した効 果の現れといえる。反対に右下部は特徵量の平均值か ら経験的に決めた 2 值化閾值ではひびわれが無い時, ノイズが 2 值化されることを示した。領域分割法の適 用などによりステップエッジの輪郭を無視するような 処理も必要なことが分かった。

\section{（iii） ノイズの除去と詳細ひびわれの抽出}

眓14は細部におけるひびわれ抽出エラ一である。画 像は原画像あるいは $1 / 4$ 縮小画像から数・の範囲を拡 大したものである。coarse to fine の過程にはノイズに 対する考案も組み込んだが，罒14(a)（b)などノイズ 


\section{表 2 実験の結果}

\begin{tabular}{|c|c|c|c|c|c|c|}
\hline \multirow[b]{2}{*}{$\begin{array}{c}\text { サンプル } \\
\text { 番号 }\end{array}$} & \multicolumn{5}{|c|}{ ひびわれ抽出結果 } & \multirow{2}{*}{$\begin{array}{c}\text { ひびわれ幅測定結果 } \\
\text { 摽準誤差 }[\mathrm{mm}]\end{array}$} \\
\hline & $\begin{array}{l}\text { ひびわれ長 }[\mathrm{cm}] \\
\text { （正解） }\end{array}$ & $\begin{array}{l}\text { 正しく認識した } \\
\text { ひびわれ長 }[\mathrm{cm}]\end{array}$ & 認識率[\%] & $\begin{array}{c}\text { 誤ってひびわれ } \\
\text { と認識した/イス } \\
{[\mathrm{cm}]}\end{array}$ & 誤諗率 [\%] & \\
\hline 1 & 114.6 & 114.6 & 100 & 13.5 & 12 & 0.13 \\
\hline 2 & 103.7 & 103.7 & 100 & 38.0 & 37 & 0.15 \\
\hline 3 & 428.0 & 333.8 & 78 & 13.4 & 4 & 0.12 \\
\hline 4 & 248.2 & 188.5 & 76 & 35.2 & 19 & 0.19 \\
\hline
\end{tabular}

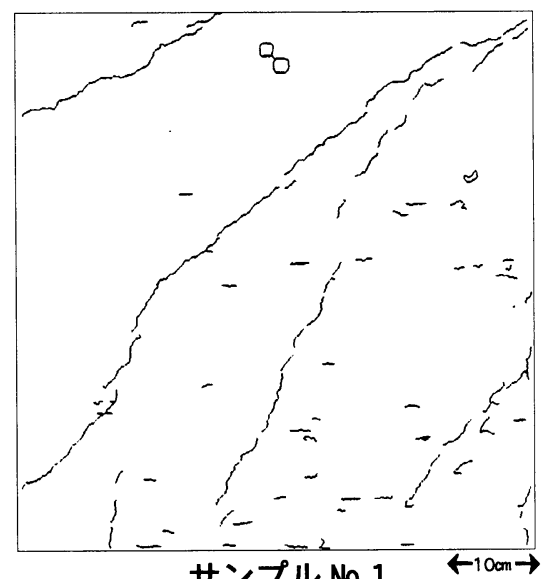

サンプル №. 1

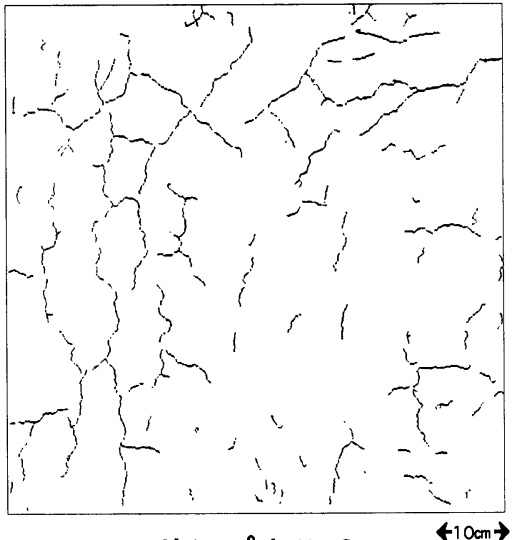

サンプル №. 3

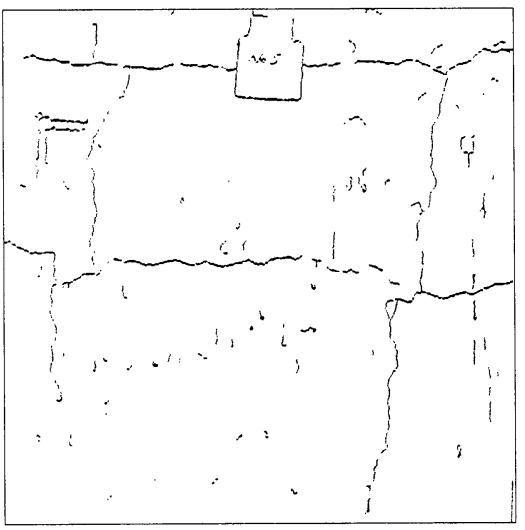

サンプル №.2

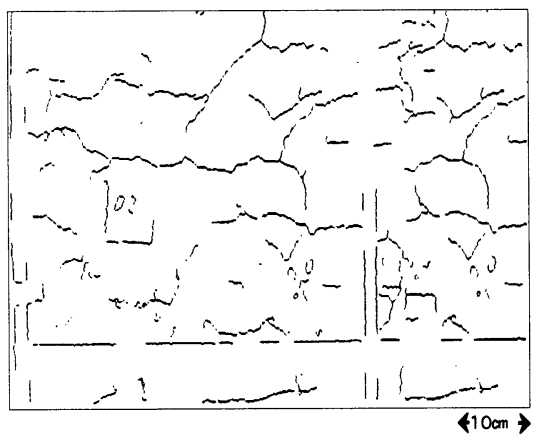

サンプル No. 4

図12 コンクリートひびわれ抽出結果 4 例

分離が不十分な箇所も確認された。図14中の折れ線は 抽出されたひびわれの中心線を示しているが，（a） (b)ともにノイズ上に中心線が位置しているところが ある。これは（a）の右図に示すとおり，2 值化状態 でひびわれとノイズが連結したのが原因である。こと に（b）はひびわれ周囲の暗部が連結したものであり， 2 值化小領域がひびわれから外れてしまい，2 值化結 果の繫ぎ合わせによりノイズが連結されたことが原因 である。 また，（c）はひびわれに析出した石灰の外側に暗部 が線上に形成されており，とぎれたひびわれが連結さ れた例である。（d）(e ）はUびわれ周辺の点状ノイズ が除去しきれず 2 值化の誤りが回復されていない。さ らに，ひびわれ中心線の点間隔が長くなっているのは 誤った移動が行われた結果である。（e ）は細いひびわ れの周りにある点状の細かなノイズが縮小画像で連結 し太いひびわれと見なされた例である。2 值化領域が 広く取られノイズがブドウの房のように連結され回復 


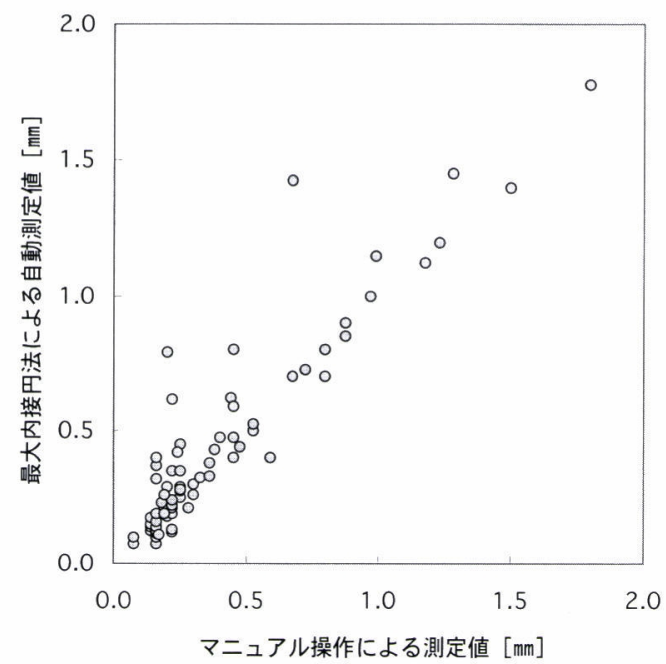

図13 ひびわれ幅の測定結果
困難に陥っている。このように細部のエラ一を検証す ると, ひびわれの存在は間違えてはいないが, 繰返し 逐次判別 2 值化結果にも誤りの発生があるのが分か る。細いひびわれを太いと䛊った際に必要となる形状 によるチェック法や回復法が新なな機能として必要な ことが分かった。

上述したように手法には幾つか改善の余地も残され たが，階層構造化画像の処理によりひびわれの形状パ ターンが抽出可能であり，また coarse to fineにより ひびわれ幅の測定が可能なことが分った。実験結果は 手法の有效性を示したものと言之, 本研究によりコン クリート構造物のひびわれ測定を合理化するシステム の実現可能性を示すことができたと考える。

\section{6. まとめ}

本研究では, コンクリート構造物の維持管理のため
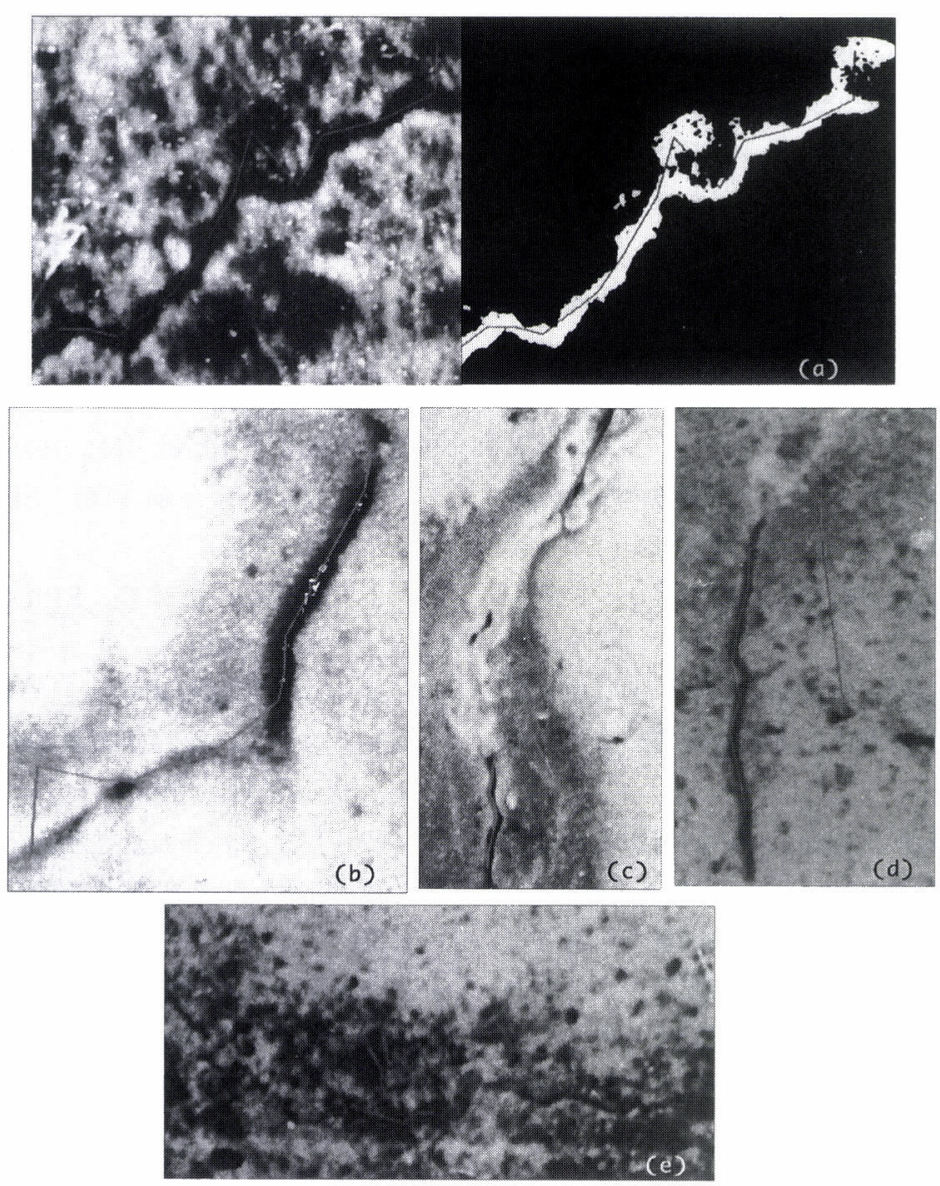

図14＼cjkstart細部におけるひびわれ抽出エラー 
巡視点検に利用するひびわれ測定装置に関して，携帯 可能なカメラで写真撮影した画像からひびわれを自動 測定する画像処理機器を想定し, 幅 $0.1 \sim 2.0 \mathrm{~mm} の ひ$ びわれの形状パターンと幅を自動測定する画像処理手 法を提案した。

手法は階層構造化した画像をべースとし, 微細ひび われの線構造を保存しノイズを低減する論理フィル夕 処理と縮小処理, 円形フィルタの作用性を応用した線 構造の抽出, 計算コストを抑之るためにパーパシブ・ ビジョン的な処理を取り入れた coarse to fineによる ひびわれの自動 2 值化, 最大内接円法によるひびわれ 幅の測定などから構成した。

この手法を実際のコンクリート構造物のひびわれ画 像に適用し検証した結果, 以下を得た。

(1)ひびわれの線構造を残す画像の縮小により, 带領域 とみなされた幅の太いひびわれは徐々に幅の狭い線 構造に変換され, 一方で細いひびわれは縮小画像に おいても情報が保持され, 円形フィル夕によりひび われの形状パターンが抽出できた。実験では $80 \%$ 以 上のひびわれが抽出可能であった。

(2)画像を縮小しマクロ的視野に基づき形状パターンを 抽出するため, 局部的な線状ノイズをひびわれと誤 る危険性が小さくなった。

(3)円形フィルタの適用では画像を分割し 2 值化閾值を 決定することにより，コンクリート表面の污れなど ひびわれ抽出を妨げるノイズの影響を抑えることが できた。

(4)抽出したひびわれの形状パターンと概略のひびわれ 幅を初期值とする coarse to fine 画像処理により標 準誤差 $0.12 \sim 0.19 \mathrm{~mm}$ でひびわれ幅の測定が可能と なった。

(5)精細な画像になるに従って増加するデー夕処理量は 概略の形状パターンを利用した画像処理により効率 化が図られた。

(6)細部におけるひびわれの抽出エラーに対する処理手 法の改良点が明らかとなった。

以上のとおり, 実用システムの構築には幾つか改善す べき課題は残されたが, 従来の現場作業の多くを室内 作業に置き換える手法を示すことができたと考える。

(受付日1998.3.6，受理日1998.5.15)
健全度評価について, コンクリート構造物の耐久性 診断に関するシンポジウム講演予稿集, 1988.

2) 島村秀樹ほか: 路面画像の自動ひびわれ抽出, 写 真測量とリモートセンシング, Vol. 33, No.6, pp. 16-25, 1994.

3 ) 土木学会編：コンクリート仕方書

4) Kodak 社：フィルム・テクニカルデータ

5 ）富士写真フィルム 社：フィルム・テクニカルデー 夕

6) L.G. Shapiro: Data Structure for Picture Processing:a survey, Computer Graphics and Image Processing, Vol. 11, No. 3, pp.162-184, 1979.

7 ) 服部進ほか：空中写真によるステレオマッチング のための多段階相関法の改良 (2), 写真測量とリ モートセンシング, Vol. 25, No. 2, pp.24-38, 1986.

8 ）興水大和：産業応用から見た画像処理アルゴリズ ムの動向, O plus E 別冊号, 1986.

9 ) Toni Schenk, etal.: Towards an Autonomous System for Orienting Digital Steropairs, Photogrammetric Engineering \& Remote Sensing, Vol. 57, No. 8, pp.1057-1064, 1991.

10) Mengxiang Li : Hierarchical Multipoint Matching, Photogrammetric Engineering \& Remote Sensing, Vol. 57, No. 8, pp.1039-1047, 1991.

11 a ) 長尾真訳 : デジタル画像処理, 近代科学社, pp. 198-204, 1978.

11 b) 同じく, pp.162-166, 1978.

12）電子技術総合研究所：SPIDER ユーザーズマ ニュアル, 1980.

13）共同システム開発: SPIDER- 2 ユーザーズマ ニュアル, 1986.

14）鈴木英夫：肺癌検出を目的とした胸部 $X$ 線画像 解析システム, 第16回画像工学コンファレンス論文 集, pp.145-148, 1985.

15）大津展之：判別および最小 2 乗基準に基づく自動 閾值選択法, 電学誌, Vol. J63-D, No. 4, pp.349-356, 1980.

16）斉藤泰一：判別閾值選択法の一改良, 情報処理論 文誌, Vol.22, No.6, pp.596-599, 1981.

17）尾上守夫：画像処理ハンドブック, 昭晃堂, 1990.

\section{参考文献}

1) 杉正ほか：コンクリート構造物のひびわれによる 